Aliyev B.A., Kalashova Kh.Kh.•

DOI: 10.25108/2304-1730-1749.iolr.2019.58.31-48

\title{
Some problems of ecological safety in Azerbaijan Republic and ways of their solution
}

\begin{abstract}
Issues related to the solution of environmental problems and the provision of environmental safety are regulated by the Constitution of the Republic of Azerbaijan and relevant legislative acts adopted on its basis. The main legal basis for ensuring environmental safety in our country is the law of the Republic of Azerbaijan 'On Ecological Safety'. The main purpose of this law is to investigate the dangers of natural and anthropogenic factors affecting human life and health, society, its material and spiritual values, environment, atmospheric air, cosmic space, water objects, earth's surface, soil, natural landscape, plant and animal kingdom to determine the legal basis for protection.

It should be noted that 'environmental safety' is one of the types of security that threatens human beings, such as nuclear and nuclear safety. On June 4, 1999, the Law of the Republic of Azerbaijan 'On Ecological Safety' was adopted. Ecological safety is understood to mean that the vital interests of people and society are protected from the dangers of anthropogenic and natural environmental impacts.
\end{abstract}

The purpose of environmental safety is to protect the life and health of a person, the society, its material and spiritual values, the environment, including the atmosphere, space, water objects, to protect.

The reasons for the environmental hazard are as follows:

\footnotetext{
"Aliyev Bakhtiyar Abdurahman oglu - PhD in Law, Associate Professor, Head of Department "Legal provision of state security" of the İnstitute of Law and Human Rights of the National Academy of Sciences of the Republic of Azerbaijan (Azerbaijan). Email:antiterror-baku@mail.ru

Kalashova Khayala Khaqani qizi - Senior Research Fellow of "The legal provision of state security" Department of the İnstitute of Law and Human Rights (Azerbaijan). Email: xayala_kalashova@yahoo.com
} 
- Experience in resolving social, economic and technological problems without taking into account the degree of impact of natural environment on the interaction of nature, society and people on the preservation of favorable conditions of people's environment;

- The most intense pollution and disruption of the natural environment. Violation of the ecological balance in the planet and especially in areas, where industry is strongly developed, where the natural resources are most commonly used. Ineffective protection of natural environment;

- Lack of ecological and anthropogenic load, loss of soil productivity, exhaustion of drinking water, reduction and loss of gene pool of flora and fauna;

- Public, state and legal assessments of direct relationships with the emergence of new diseases, the level of mortality and the effects of environmental conditions;

- The main ecological security of population, improvement of ecological concepts, not the form and method of teaching that the low level.

Environmental security in some parts of the content is included:

The environmental safety system is a collection of legislative, technical, medical and biological activities aimed at maintaining balance between biosphere and anthropogenic and natural forces.

Subjects of human, society, state, and biosphere are the subjects of ecological security.

Environmental security facilities - security agents lives of important interests: Human rights, material and spiritual needs, state and society as the basis for natural resources and environment.

Health is not just the absence of illness, but the physical, mental and social well-being. The purpose of protection of public health, as well as the quantity and quality of performance is important to determine and evaluate its situation, not 
only the safety of environmental protection. Such data are near the border, the degree of stability of ecosystems its condition.

Keywords: ecological security and environmental risks; protection of the environment; environmental balance; ecological problems; ecological state; national security concept.

Environmental safety issues, which are a key factor in ensuring sustainable development, are part of the national security concept. According to its structure and national priorities, environmental safety has been included in many countries' national security strategies. In its national security concept Azerbaijan, an equal member of the world community, also pays special attention to environmental issues and environmental threats.

In this regard, the Azerbaijani National security concept (NSC) called 'Environmental problems' in our country shows the potential environmental danger. One of them inherited from the former USSR, the oil production in Absheron peninsula is related. That is shown here: "Environmental problems are mainly in the Absheron peninsula and in Caspian Sea were carried out for decades without taking into account the environmental impact of oil production associated with imperfect methods of meeting the requirements for energy resources in Azerbaijan Republic of the Soviet Union" [3, p. 389].

At the initiative of the Ecological Scientists of our country, an operative 'Center' was established in 2002 on the occupied territories of Azerbaijan in the MENR to define destructive impact on the environment and natural resources. The main purpose of the Center is to study the ecological situation in the occupied territories, identify destructive damage to the environment, and find out about the sources of environmental threats in the occupied territories. After the establishment of the 'Center' in October 2002, we published a comprehensive report on the 
geographical, ecological, fauna and flora of our occupied territories and published in the form of a collection [4, p. 243].

In recent years, President Ilham Aliyev has issued a decree on the implementation of many activities related to environmental protection and environmental safety:

- On Approval of the "Complex Action Measures for 2006-2010 on the Improvement of the Environmental Situation in the Republic of Azerbaijan".

- Order No. 2244 of the Republic of Azerbaijan "On some measures to protect the Caspian Sea from pollution", which came into the force on 20 June 2007.

- Order No. 2245 of the Republic of Azerbaijan "On Some Measures to Improve the Provision of Ecologically Clean Water in Population", which came into the force on 20 June 2007.

- Order No. 2868 of the Republic of Azerbaijan "On Measures to Improve Management of Greenery in the Republic of Azerbaijan", which entered into the force on 13 June 2008.

- Order No. 2867 of the Republic of Azerbaijan "On Additional Measures to Protect the Caspian Sea from pollution", which entered into the force on 13 June 2008 .

- Order No. 2983 of the Republic of Azerbaijan “On Improvement of Domestic Waste Management in Baku City" on August 6, 2008.

One of the reasons why the pollution of the environment in the western countries is more intensive is the overriding of environmental problems when the economic problems are solved in these countries, and the domination of the thesis 'enterprise's profit is above all'. According to the United Nations, about 50\% of environmental pollution lies only in the United States [5, p. 109].

Ecological risk theory is the basis of the concept of environmental safety around the world. It is the definition of the accepted level of risk, which is the part of its essence in the theory. Until recently, environmental safety standards all 
around the world were justified in accordance with the 'absolute security concept'. Ecological and economic balance in nature has a great impact on various production areas and toxic gases separated from transport. Toxic pollution from vehicles accounted for $60 \%$, and the rest - organic fuels like coal, oil and gas, peat and other production areas accounted for, and allocated a total of about. In the world of organic fuel - 64 percent, the share of electricity produced in nuclear fuel - 17 percent [6, p.1].

Energy production in Azerbaijan accounts for about $87 \%$ of thermal power plants (the CHP), 13\% - for hydropower plants (HPS).In the first place, environmentally and economically more profitable, which is a more important place is given to the use of solar and wind energy in Azerbaijan. Using their resources, such as practically does not change and is not reduced, that is by nature continuously restored. Nonrenewable energy sources like coal, oil, gas, peat and other concerns and to be burned [7, p. 3].

Ecological safety is at global, regional and local levels. The level of global management of ecological safety generally envisages the forecasting and monitoring of processes occurring in the biosphere and its components. In the second half of the twentieth century, these processes were reflected in global climate change, the appearance of 'greenhouse effect', ozone depletion, desertification of the planet, and pollution of the world ocean.

The essence of global control and governance is the use of the biosphere and environmental sustainability mechanism. It is oriented to the body of the living organisms included in the biosphere. Global environmental safety management is the prerequisite of intergovernmental relations at the UN, UNESCO, UNEP and other international organizations. Management at this level includes the adoption of international environmental conventions, the implementation of intergovernmental environmental programs, and the establishment of 
intergovernmental forces for the prevention of natural or anthropogenic environmental problems.

A number of large-scale environmental problems at the global level have been relatively resolved. Prohibition of nuclear weapons in all areas, except underground testing, is a great achievement of the international community $[8, \mathrm{p}$. 2].

Regional level covers large geographical or economic zones, and sometimes territories of several states. Control and governance are carried out at the level of government and interstate relations. At this level, the environmental safety management system includes:

- ecology of the economy;

- new ecologically safe technologies;

- preventing the recovery of the environment and the economic growth rate, which serves to the efficient use of natural resources.

The level of local governance of environmental safety may be affected by urban, regional, metallurgical, chemical, oil refineries, mining industry, wastes, streams, etc. control. Environmental safety management is carried out at the level of administrative divisions of separate cities, regions, enterprises with the involvement of relevant services responsible for sanitation and nature protection activities.

The solution of specific local problems determines the possibility of achieving the objectives of environmental safety at regional and global levels. Regardless of the level of environmental management, the key management object is a natural environment.

That is why, in any level of environmental safety management, there is absolutely economic, legal, administrative, educational, and analytical analysis of culture. As we know, many industries, including metallurgy, chemicals, oil refineries, have a great deal of environmental pollutants. In recent years, the 
importance of taking immediate measures to deteriorate atmospheric air in some regions and to improve it has led to the active work on the creation and implementation of modern environmental monitoring systems. It is important to use environmentally sound technologies to ensure environmental safety. [10, p. 3]

The main environmental problems in our country are in principle consistent with environmental problems. It is advisable to pay particular attention to a number of points.

a) the formation of zones not controlled by the Azerbaijani state as a result of the occupation by the aggressive separatist forces of the majority of the territory of the republic, the violation of the integrity of the republican socio-economic, cultural complex, the rational nature of the natural environment.

b) Pollution of the biosphere with hazardous wastes, particularly oil and artificial waste, requires urgent action.

c) Noise abuses (in particular in urban areas), overloading of some areas around the city and the city, failure to comply with the required standards and norms in the construction of skyscrapers.

d) Decrease of productive lands, free areas to be used for recreation, systematic, non-routine maintenance of restorative works, etc.

Improving the ecological situation in the country is collaborating with the countries of the world to overcome existing priorities. For example, the UN Environment Program sends experts to study the ecological situation of Azerbaijan. The ecological situation of the Caspian, Absheron region has been studied and the program has been developed to overcome the crisis, and an international fund has been established. In Tehran, in May 1998, the Conference of the Caspian littoral States was convened to implement the Caspian Environmental Program. The conference was attended by representatives of the World Bank, UNDP, Global Environment Facility, World Meteorological Center and other international organizations [11, p. 2]. 
The basic terms of environmental safety are as follows:

- conservation and improvement of natural environment;

- rational use of natural resources;

- giving a healthy environment to future generations.

It is possible to conclude that the main national interests of the Republic of Azerbaijan in the field of ecology are the creation of safe ecological and technological conditions for the society, as well as the protection of the environment.

Thus, in this article, such a conclusion is drawn:

1. It is essential to maintain regional and international cooperation at all times for the successful solution of extremely important environmental problems such as reducing harmful substances into atmospheric air, preventing river pollution, improving the ecological status of the Caspian Sea, maintaining ozone layer and biodiversity.

2. The adoption of programs that form the basis of the country's environmental strategy, signing relevant decrees and orders, protecting the environment, living in a healthy environment and rational use of natural resources serve to address existing environmental problems in Azerbaijan.

3. Environmental safety should be assessed as an integral part of international and national security. More specifically, the environmental safety criterion should be fully coordinated with other types of security.

\section{References}

1. Atashova U., Sultanov R., Sadigova N. Umumi ekologiya [General ecology]. Baku, 2010, 193 p.

2. Agayev T., Ahmadov Sh., Khalilov T. Ekolozhi tehlukesizlik [Environmental safety]. Sumgayit, 2013, 163 p. 
3. Huseynov E., Hashimov A., Mammadov Q., Mammadova S. Insan ekologiyasi [Human Ecology]. Baku, 2015, 736 p.

4. Mammadov Q., Mammadova S., Huseynov E., Hashimov A. Sosial ekologiyasi [Social ecology]. Baku, 2015, 389 p.

5. Khalilov T., Zeynalova M. Global ekolozhi problemleri [Global environmental problems]. Baku, 2014, 212 p.

6. http://www.e-qanun.az/framework/3851

7. https://az.wikipedia.org/wiki/Ekology_t\%C9\%99hl\%C3\%BCk\%C9\%99

8. http://www.vertic.org/media/National\%20Legislation/Azerbaijan/AZ_Law _Environmental_Protection.pdf

9. http://eco.gov.az/en/19- Legislation

10. http://www.ombudsman.gov.az/en/view/pages/79

11. http://www.rights.az/qanunvericilik/mecelle/93-azerbaycanrespublikasinin-in administrative-xetalar-mecellesi/230 